\title{
Bank of Weed Seeds in Agrosystems in the Brazilian CerRado ${ }^{1}$
}

\author{
Banco de Sementes de Plantas Daninhas em Agrossistemas no Cerrado Brasileiro
}

\author{
CARDOSO, I.S. ${ }^{2}$, SOARES, M.P. ${ }^{3}$, ARAÚJO, V.T. ${ }^{2}$, CABRAL, P.H.R. ${ }^{2}$, JAKELAITIS, A. ${ }^{2}$, and \\ MADALÃO, J.C. ${ }^{4}$
}

\begin{abstract}
The seed bank is the reserve of viable seeds found in the soil and is related to diversity and abundance of species that make up the weed populations. This study aimed to determine the seed bank in four distinct environments (grazing area, area of vegetables, annual crop area and perennial crop area) in two seasons (rainy and dry season). To determine the seed bank, each environment was divided into four sub-areas of 0.2 hectares, considering that each area was a repetition, totaling 16 experimental units. Samples of $0.8 \mathrm{~kg}$ were taken from each area, and each sample was distributed on a plastic tray and allowed to germinate in a greenhouse. The density of the individuals was determined by observing the number of emerging seedlings in the trays, performing the counting at every 18 days. Evaluations were made for ninety days in each season. The germination curve was calculated, as well as the Shannon diversity index $\left(\mathrm{H}^{\prime}\right)$, the Sorensen similarity index and the relative importance. The seven main species identified in the environments were Cyperus rotundus, Nicandra physaloides, Galinsoga parviflora, Alternanthera tenella, Panicum maximum, Portulaca oleracea and Eleusine indica. Among the studied environments, during the rainy season, the highest number of individuals was found in annual crop and the greatest diversity in the evergreen environment. During the dry season, the number and diversity of individuals were lower and similar in all environments.
\end{abstract}

Keywords: rainy season, dry season, Shannon index, relative importance, diversity.

RESUMO - O banco de sementes é a reserva de sementes viáveis encontradas no solo e está relacionado à diversidade e abundância das espécies que compõem as populações de plantas daninhas. Com este estudo, objetivou-se determinar o banco de sementes em quatro ambientes distintos (área de pastagem, área de hortaliças, área de cultura anual e área de cultura perene), em duas épocas do ano (estação das chuvas e da seca). Para determinação do banco de sementes, cada ambiente foi dividido em quatro subáreas de 0,2 ha, sendo cada uma delas uma repetição, totalizando 16 unidades experimentais. Retiraram-se amostras de $0,8 \mathrm{~kg}$ em cada subárea, as quais foram distribuidas em bandeja plástica e levadas para germinar em casa de vegetação. Foi determinada a densidade de individuos, observando-se o número de plântulas emergentes nas bandejas, realizando-se a contagem a cada 18 dias. As avaliações foram feitas durante 90 dias em cada estação. Foram calculados a curva de germinação, o indice de diversidade de Shannon ( $\left.H^{\prime}\right)$, o indice de similaridade de Sorensen e a importância relativa. As sete principais espécies identificadas nos ambientes foram Cyperus rotundus, Nicandra physaloides, Galinsoga parviflora, Alternanthera tenella, Panicum maximum, Portulaca oleracea e Eleusine indica. Entre os ambientes estudados, na época das chuvas, o maior número de indivíduos foi encontrado no cultivo anual, e a maior diversidade, no ambiente perene. Na época seca, o número e a diversidade de individuos foram menores e semelhantes em todos os ambientes.

Palavras-chave: estação das chuvas, estação da seca, índice de Shannon, importância relativa, diversidade.

Recebido para publicação em 15.9.2015 e aprovado em 27.11.2015.

2 Instituto Federal Goiano, Rio Verde-GO, Brasil, <isabellacardoso-rv@hotmail.com>; ${ }^{3}$ Instituto Federal do Norte de Minas Gerais, Salinas-MG, Brasil; ${ }^{4}$ Universidade Federal do Espírito Santo, São Mateus-ES, Brasil. 


\section{INTRODUCTION}

Weeds are majorly important for agroecosystems. Studying them is fundamental to understand their interference on cultured plants and management strategies. The main problem caused by weeds is the competition for water, light and nutrients, in addition to being secondary hosts of plague-insects and pathogens.

It is important to point out that the interference does not encompass the entire culture cycle and that the control of weeds must be conducted during the adequate period, that is, during the period of total prevention of the interference (PTPI) of these plants on the cultures (Yirefu et al., 2012; Singha et al., 2014; Tursun et al., 2015; Matloob et al., 2015), also considering the structure of the infesting community on the environment, represented by the occurring species, their density and distribution.

The phytosociology may be characterized as an important tool for this management, since it studies the vegetable communities from the floristic and structural perspective (Braun-Blanquet, 1979), comparing the weed populations throughout time and space. The floristic composition of an environment may directly interfere on the seed bank of an area. The seed bank is the reserve of viable seeds found on the soil (Roberts, 1981). This reserve is the sum of seeds that were produced and introduced throughout time and that remained alive and dormant, with recently produced seeds. Its structure relates to the diversity and abundance of the species that constitute the weed populations on the soil (Radosevich et al., 1997), and it is strongly influenced by the management used (Santos et al., 2015).

On cultured soils, the seed bank is usually dominated by few weed species, among which, the species that are difficult to control are the ones that stand out, or those that are better adapted to the culture systems (Ikeda et al., 2007; Gomes Jr. and Christoffoleti, 2008; Bürger et al., 2015).

Among the main survival mechanisms of infesting plants on the seed bank are the longevity and dormancy. Longevity varies according to the species, characteristics of the seeds, climatic conditions and how deep they are on the soil (Santos et al., 2015). Dormancy on the other hand, which is an intrinsic characteristic of the seeds, represents the main preservation mechanism of the species on the seed bank, since it may assure their survival, even under adverse conditions (Vivian et al., 2008).

Throughout time, weeds were selected on the agroecosystems. Their perpetuation was conditioned to the interaction between the phenotypical plasticity of each individual and processes that, on the long term, enabled the adaptive flexibility of these species considering the changes in the environment (Fernandez, 1979).

Communities of weeds may vary significantly as a response to edaphic and climatic characteristics and to the agronomic practices used, such as culture systems and application of herbicides (Concenço et al., 2013; Hosseini et al., 2014; Bürger et al., 2015). Within this context, the objective of this study was to determine the seed bank in four different environment, during two times of the year.

\section{MATERIAL AND METHODS}

The contiguous areas were selected on a flat relief and on the same soil class (distroferric Red Latosol), collecting the samples on two times of the year (rainy and dry season). The evaluated environments were: (I) cultured area with maize culture on the no-tillage sowing system with no soil disturbance, soil correction and fertilizations conducted according to the explored culture the control of weeds was made with the selective herbicides atrazine and nicosulfuron; (II) area with olericultures, intensively managed environment with constant soil turn over, fertility and irrigation maintenance, rotation of cultures - the management of weeds was made with mechanical turn over and manual hoeing; (III) cultured area with a perennial culture (Jatropha), for four years, with no soil turn over and with overhead irrigation during the dry season - the weed control was made with manual hoeing, mowing and the use of glyphosate on a directed application; and (IV) area with a history of 
grazing of Urochloa brizantha five years before, compacted due to the presence of animals, lack of correction and maintenance of the soil fertility - the control of weeds was made with mowing.

In order to determine the seed bank, each environment was divided into four sub-areas of 0.2 ha; each sub-area was considered one experimental unit, and 16 simple samples were taken from each one. The collections were made on a systematic manner, following a "W" format. The simple samples from each sub-area were homogenized, obtaining four compound samples in each environment. The soil samples were taken at a depth of 0 to $10 \mathrm{~cm}$, with the help of a auger with $5 \mathrm{~cm}$ of diameter. The compound samples were sifted, on a $2 \mathrm{~mm}$ stainless steel mash sift, and dried in the open air; after this stage, a portion of $0.8 \mathrm{~kg}$ was taken from each sample, which were uniformly distributed on plastic trays ( $50 \times 30 \times 8 \mathrm{~cm}$ with a hole on the bottom) and allowed to germinate in a greenhouse. They were randomly distributed and irrigated, when necessary. The temperature in the greenhouse varied between 22 and $29{ }^{\circ} \mathrm{C}$, and the relative humidity was between 60 and $75 \%$.

The density of the individuals was determined observing the number of seedlings that emerged on the trays. The counting was conducted at every 18 days; this period was necessary for the new germination and emergency flow to occur, and for the new plants to be developed enough in order for them to be identified. At every counting, the seedlings were identified and removed, in order to allow the new emergency flow; at every evaluation period, the position of the trays changed, in order to avoid the favoring of evaluated samples or environments. Five evaluations were conducted on a period of 90 days for each season (rainy and dry) (Caetano et al., 2001).

The germination curve was calculated by the sum of the accumulated number of emerged seedlings throughout the observation time. The relative importance was determined, which determines the relationship of each species with the others found on the area, based on the density, frequency and abundance on the samples. The Shannon diversity index
$\left(H^{\prime}\right)$, the Pielou index $\left(\mathrm{J}^{\prime}\right)$ and the index of similarity of Sorensen (ISS) were also calculated, where:

$$
H^{\prime}=-\sum_{i=0}^{n} p i * \ln p i
$$

considering that $\ln$ is the Napierian logarithm; $p i=n i / N ; n i$, the number of individuals sampled from species $i$; and $N$ is the total number of sampled individuals.

$\mathrm{J}^{\prime}=\mathrm{H}^{\prime} / \mathrm{H}_{\max }$, in which $\mathrm{H}^{\prime}$ is Shannon's diversity index; $\mathrm{H}_{\max }=\ln (\mathrm{S})$, considering that $\mathrm{S}$ is the total number of species.

ISS $=(2 . c) /(\mathrm{S} 1+\mathrm{S} 2)$, considering that $\mathrm{c}$ is the number of common species on two environments; $\mathrm{S} 1$, the number of species from environment $\mathrm{A}$; and $\mathrm{S} 2$, the number of species from environment $\mathrm{B}$.

\section{RESULTS AND DISCUSSION}

On the seed bank, 35 species were identified, distributed into 14 families (Table 1), considering that most of them belonged to the Poaceae (9), Asteraceae (7), Amaranthaceae (4) and Fabaceae (3) families. During the evaluations, 30 species were found during the rainy season, and 29 species during the dry season, and 24 species were present on both times.

The total density of the weeds emerged during both seasons was 4,002 individuals. There was a higher number of seedlings emerged during the rainy season, characterizing $61.54 \%(2,463$ individuals); during the dry season, $38.46 \%$ of emerged seedlings were observed, totaling 1,539 individuals (Table 1).

Considering the total of emerged plants in all evaluations $(100 \%)$, it was possible to observe the emergence of weeds during the rainy season (Figure 1): on the first evaluation, 335 seedlings had already emerged (13.6\%); on the second, 780 (31.67\%); on the third, 1,225 (49.7\%); on the fourth, 1,740 (70.64\%); and on the fifth, 2,463 (100\%). During the dry season, the behavior was similar; however, the number of emerged seedlings from the second evaluation on was lower than during the rainy season. Therefore, the emergence on the first 
Table 1 - Number of individuals, species and families of weeds found on a seed bank during the evaluated times

\begin{tabular}{|c|c|c|c|c|}
\hline \multirow{2}{*}{ Family/Species } & \multirow{2}{*}{ Acronym } & \multirow{2}{*}{ Common Name } & \multicolumn{2}{|c|}{ Season } \\
\hline & & & Rain & Dry \\
\hline \multicolumn{5}{|l|}{ Amaranthaceae } \\
\hline Alternanthera tenella Colla & ALTTE & Joyweed & 215 & 88 \\
\hline Amaranthus hybridus L. & AMAHY & Slender amaranth & 178 & 51 \\
\hline Amaranthus retroflexus L. & AMARE & Red-root amaranth & 95 & 15 \\
\hline Amaranthus viridis L. & AMAVI & Green amaranth & 7 & 8 \\
\hline \multicolumn{5}{|l|}{ Commelinaceae } \\
\hline Commelina benghalensis L. & COMBE & Benghal dayflower & 60 & 80 \\
\hline \multicolumn{5}{|l|}{ Asteraceae } \\
\hline Ageratum conyzoides L. & AGECO & Billygoat-weed & 14 & 1 \\
\hline Bidens pilosa $\mathrm{L}$. & BIDPI & Black-jack & 10 & 10 \\
\hline Emilia fosbergii Nicolson & EMIFO & Florida tasselflower & 76 & 1 \\
\hline Galinsoga parviflora Cav. & GALPA & Gallant soldier & 228 & 294 \\
\hline Gnaphalium coarctatum Willd. & GNACO & Elegant cudweed & 23 & 25 \\
\hline Tridax procumbens $\mathrm{L}$. & TRIPR & Coatbuttons & 21 & 63 \\
\hline Sonchus oleraceus L. & SONOL & Common sowthistle & - & 2 \\
\hline \multicolumn{5}{|l|}{ Convolvulaceae } \\
\hline Ipomoea purpurea (L.) Roth & IPOPU & Common morning glory & 22 & 1 \\
\hline \multicolumn{5}{|l|}{ Cyperaceae } \\
\hline Cyperus rotundus $\mathrm{L}$. & CYPRO & Coco-grass & 309 & 65 \\
\hline \multicolumn{5}{|l|}{ Euphorbiaceae } \\
\hline Chamaesyce hirta (L.) Millsp. & CHAHI & Asthma-plant & 16 & 134 \\
\hline \multicolumn{5}{|l|}{ Phyllanthaceae } \\
\hline Phyllanthus tenellus Roxb. & PHYTE & Leafflower & 8 & 4 \\
\hline \multicolumn{5}{|l|}{ Fabaceae } \\
\hline Crotalaria incana $\mathrm{L}$. & CROIN & Rattlepods & & 1 \\
\hline Desmosium tortuosum (Sw.) DC. & DESTO & Tick-trefoil & 2 & - \\
\hline Senna obtusifolia (L.) H.S Irwin \& Barneby & SENOB & Sicklepod & - & 2 \\
\hline \multicolumn{5}{|l|}{ Malvaceae } \\
\hline Sida rhombifolia L. & SIDRO & Arrowleaf sida & 62 & 1 \\
\hline \multicolumn{5}{|l|}{ Oxalidaceae } \\
\hline Oxalis corniculata $\mathrm{L}$. & OXACO & Creeping woodsorrel & 167 & - \\
\hline \multicolumn{5}{|l|}{ Poaceae } \\
\hline Cenchrus echinatus $\mathrm{L}$. & CENEC & Southern sandbur & 1 & - \\
\hline Digitaria horizontalis Willd. & DIGHO & Crabgrass & 50 & 14 \\
\hline Digitaria insularis (L.) Fedde & DIGIN & Sourgrass & 3 & 1 \\
\hline Eleusine indica (L.) Gaertn. & ELEIN & Goosegrass & 108 & 180 \\
\hline Eragrostis pilosa (L.) P. Beauv. & ERAPI & Indian lovegrass & 55 & - \\
\hline Panicum maximum Jacq. & PANMA & Panicgrass & 212 & 139 \\
\hline Sorghum arundinaceum (Desv.) Stapf & SORAR & Common wild sorghum & - & 61 \\
\hline Urochloa brizanta Stapf & UROBR & Beard grass & 5 & 10 \\
\hline Urochloa decumbes Stapf & UROBE & Signal grass & 3 & - \\
\hline \multicolumn{5}{|l|}{ Portulacaceae } \\
\hline Portulaca oleracea L. & POROL & Purslane & 194 & 190 \\
\hline \multicolumn{5}{|l|}{ Rubiaceae } \\
\hline Richardia brasiliensis Gomes & RICBR & Tropical Mexican clover & 5 & - \\
\hline \multicolumn{5}{|l|}{ Solanaceae } \\
\hline Nicandra physaloides (L.) Gaertn. & NICPH & Shoo-fly plant & 308 & 82 \\
\hline Solanum americanum Mill. & SOLAM & American black nightshade & 6 & 15 \\
\hline \multicolumn{5}{|l|}{ Verbenaceae } \\
\hline Duranta repens L. & DURRE & Golden dewdrop & - & 1 \\
\hline Total & & & 2463 & 1539 \\
\hline
\end{tabular}




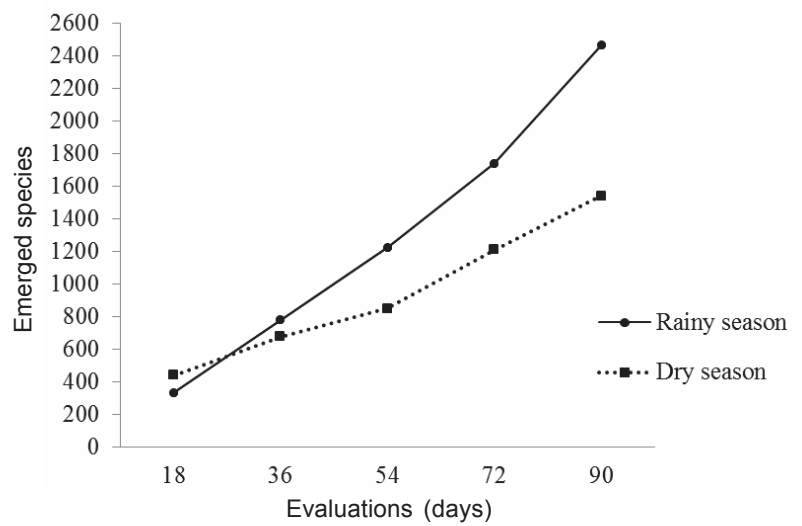

Figure 1 - Emergency of seedlings on the seed bank during the period of 90 days.

evaluation included 440 individuals (28.59\%); on the second, 676 (43.92\%); on the third, 849 (55.17\%); on the fourth, 1,209 (78.56\%); and on the fifth, 1,539 (100\%).

The fluctuations on the germination of weed seeds are due to changes on the environment and on the own seeds. When the seeds are free from dormancy factors, the temperature and soil humidity variations throughout the year are the main responsible factors for the emergency flows of these plants (Pelissari et al., 2011).

Especially on the regions where the dry and rainy seasons are well defined, the soil humidity affects the emergency flows of weeds. On more humid soils, the fluctuations on the thermal amplitude are lower, and the dormancy is indirectly affected. Therefore, the germination factors, that may be intrinsic or extrinsic to the seeds, allow certain species or even most of them to have a greater germination flow during this time of the year (Pelissari et al., 2011).

Based on the diversity index by Shanonn, it may be observed that the diversity of species during the rainy season is higher than the diversity during the dry season: 2.77 and 2.59, respectively; however, these values indicate an average diversity of weeds during both times. Shannon's diversity is considered high when it is above 3, average, between 2 and 3 , low, between 1 and 2, and very low when under 1 (Cavalcanti and Larrazábal, 2004). Silva et al. (2014) observed an average diversity of weed seeds on cultured areas with upland rice, with
H' values varying between 2.27 and 2.45 . Mesquita et al. (2013) obtained H'values for the floristic diversity of the seed bank of 2.66 and 2.53 on the rice culture with the slash and burn system.

Considering the five most representative species during the rainy season (C. rotundus, N. physaloides, G. parviflora, A. tenella and $P$. maximum), they total 1,272 individuals, representing $51.64 \%$ of the total of identified individuals, while the five most representative species of the dry season (G. parviflora, $P$. oleracea, E. indica, C. hirta and P. maximum) totaled only 937 individuals, representing $60.88 \%$. This fact evidences the higher diversity of species during the rainy period, since, even with the larger number of individuals, when only the five main species are considered, the representativeness regarding the total of individuals is lower than during the dry season, showing that the distribution of species is more uniform during the rainy season.

When considering the number of individuals found on each environment (Table 2), it is observed that, during the rainy season, the environment that stood out the most was the annual maize culture, in which the monoculture management characteristics favor the occurrence of certain weed species, mainly from the Amaranthaceae, Asteraceae and Solanaceae families, on the seed bank; however, the diversity of species was lower than on the perennial culture area.

Any change to the agro-environments, including the soil turn over and fertilization, causes changes to the weed seed bank. The wealth of species, abundance and diversity are highly dependent on the disturbance levels on these environments. Hosseini et al. (2014) verified a lower diversity of weeds on grazing and orchard areas, in relation to the annual culture area. Usually, more diversified environments require the weeds to be managed with some complementation or more combinations of herbicides, due to the different susceptibility of species.

On the olericulture area, the diversity of species was similar to the maize annual culture area (Table 2). Both culture systems are characterized by the high occurrence of 
Table 2 - Number of individuals by Family of weeds found on different assisted environments, during two times of the year, and their diversity indexes

\begin{tabular}{|c|c|c|c|c|c|c|c|c|}
\hline \multirow{2}{*}{ Families } & \multicolumn{4}{|c|}{ Environments $^{\underline{1} /}$ (rain) } & \multicolumn{4}{|c|}{ Environments $^{\underline{1} /}$ (dry) } \\
\hline & I & II & III & IV & I & II & III & IV \\
\hline Amaranthaceae & 182 & 91 & 164 & 58 & 57 & 36 & 40 & 29 \\
\hline Commelinaceae & 6 & 3 & 45 & 6 & 6 & 15 & 50 & 9 \\
\hline Asteraceae & 137 & 155 & 62 & 18 & 99 & 170 & 69 & 82 \\
\hline Convolvulaceae & 4 & 13 & 1 & 4 & 0 & 0 & 0 & 1 \\
\hline Cyperaceae & 45 & 14 & 58 & 368 & 9 & 7 & 25 & 24 \\
\hline Euphorbiaceae & 7 & 11 & 2 & 4 & 26 & 33 & 73 & 6 \\
\hline Fabaceae & 2 & 0 & 0 & 0 & 1 & 1 & 0 & 1 \\
\hline Malvaceae & 12 & 11 & 30 & 9 & 0 & 0 & 1 & 0 \\
\hline Oxalidaceae & 26 & 40 & 58 & 43 & 0 & 0 & 0 & 0 \\
\hline Poaceae & 67 & 262 & 82 & 25 & 79 & 157 & 139 & 30 \\
\hline Portulacaceae & 69 & 15 & 46 & 64 & 30 & 13 & 99 & 48 \\
\hline Rubiaceae & 5 & 0 & 0 & 0 & 0 & 0 & 0 & 0 \\
\hline Solanaceae & 255 & 2 & 17 & 40 & 60 & 1 & 12 & 24 \\
\hline Verbenaceae & 0 & 0 & 0 & 0 & 0 & 1 & 0 & 0 \\
\hline Total of individuals & 817 & 617 & 565 & 639 & 367 & 434 & 508 & 254 \\
\hline Shanonn Index & 2.36 & 2.35 & 2.61 & 1.70 & 2.42 & 2.04 & 2.41 & 2.47 \\
\hline Equitability or Pielou Index & 0.70 & 0.77 & 0.83 & 0.55 & 0.84 & 0.68 & 0.79 & 0.78 \\
\hline
\end{tabular}

1/I (annual culture area), II (olericulture area), III (perennial culture area) and IV (grazing area).

disturbances, such as the preparation of the soil and the application of herbicides, disturbing the environment more intensively. On grazing areas, the diversity was low, since this is a very peculiar, poorly managed and compacted environment, determining that only the species with higher adaptation capacity to these conditions will germinate and proliferate. Ferreira et al. (2014), when studying the diversity of weeds on degraded grazing areas on different locations of the Médio Vale do Rio Doce, observed a large diversity across the studied areas; however, within each location, there was a higher diversity on some places and, on others, the diversity was very low. Jakelaitis et al. (2014) found low values for Shanonn's index (between 1.33 and 1.70) on cultured areas with pastures.

During the dry season, the number of individuals was lower than on the rainy season, but it was similar on all environments. The highest diversity was observed on the olericulture area; however, Shanonn's index indicated an average diversity on all environments. Therefore, it is observed that the time of the year was a more determining factor for the composition of the seed bank than the studied environments.

In general, the families with a larger number of emerged individuals on a seed bank were Amaranthaceae, Asteraceae and Poaceae. The latter, on the grazing area, had a lower number of individuals in relation to the other areas; this occurred due to the fact that the grass species of weeds develop on a much reduced scale on this system, not promoting the seed rain. Usually, the grass seeds show a relatively short longevity and, on the grazing system, they are subjected to germination followed by death, due to the difficulty in trespassing the dense pasture layer and the predation by the animals on the location (Pitelli, 1998).

In general, the seed bank on both seasons was rather homogeneous. Among the tem main species found during the rainy season, seven were also among the most representative ones during the dry season. However, the fact that the species are observed on both samplings does not mean that they have the same importance on all environments. 
Alternanthera tenella and N. physaloides were relatively more important on environment I (annual culture area). Species G. parviflora and P. maximum were relatively more important on environment II (olericulture area); G. parviflora was also majorly important on environment I during the dry season. Species C. rotundus was more important on environment IV (grazing area); on that environment, E. indica was also majorly important; however, during the rainy season; on the dry season, P. oleracea also stood out. On environment IV (grazing area), $P$. oleracea was the most important species, and, during the dry season, G. parviflora also stood out (Figure 2).

Actual weeds have some characteristics that cause them to dominate the environment and stand out in relation to other plants, such as the great production of propagules, alternative propagation media, dormancy, quick initial growth, maintenance of the metabolism even under low humidity conditions, soil fertility and access to light (Silva et al., 2007). Due to this reason, and due to the great selection pressure they have on agro-ecosystems, the most common species found on the studied environment stand out in relation to the others, that is, they are better adjusted to the adverse conditions found, which is a normal tendency in the field.

The greatest relative importance was well distributed between monocotyledons and dicotyledons; however, in general, most species found on the seed bank are dicotyledons. In addition, Kuva et al. (2007), when studying the

\section{口I 圆 II 口III $\square$ IV}

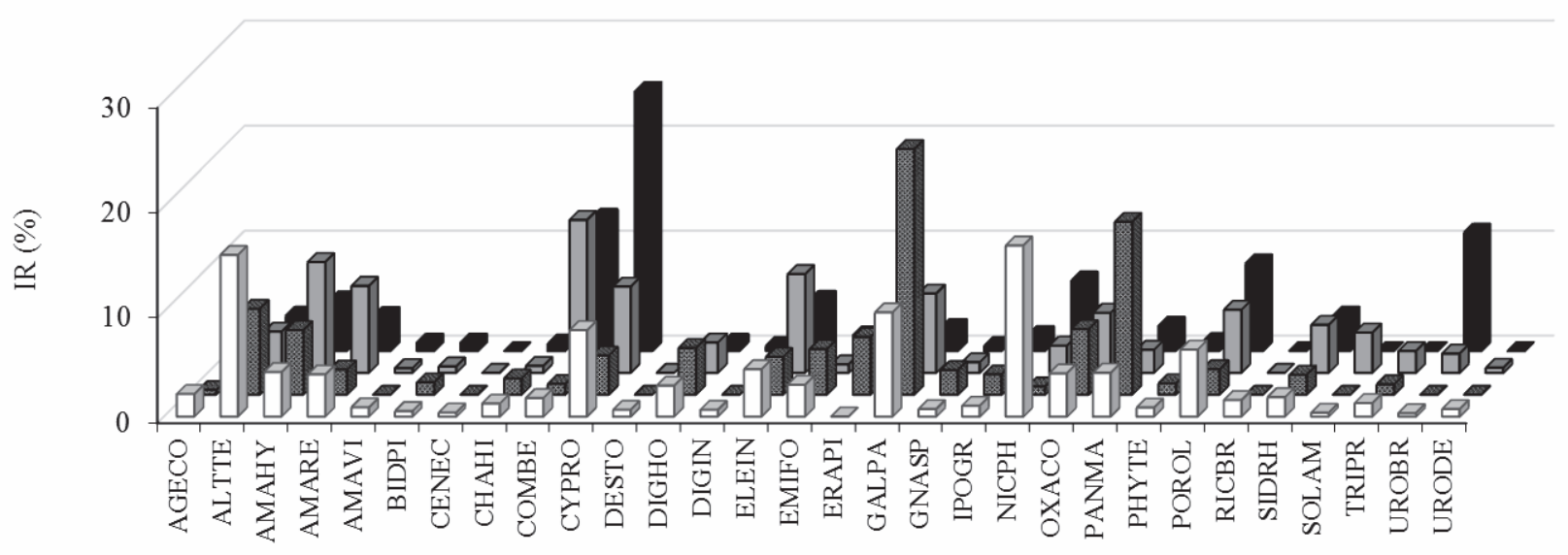

(B)

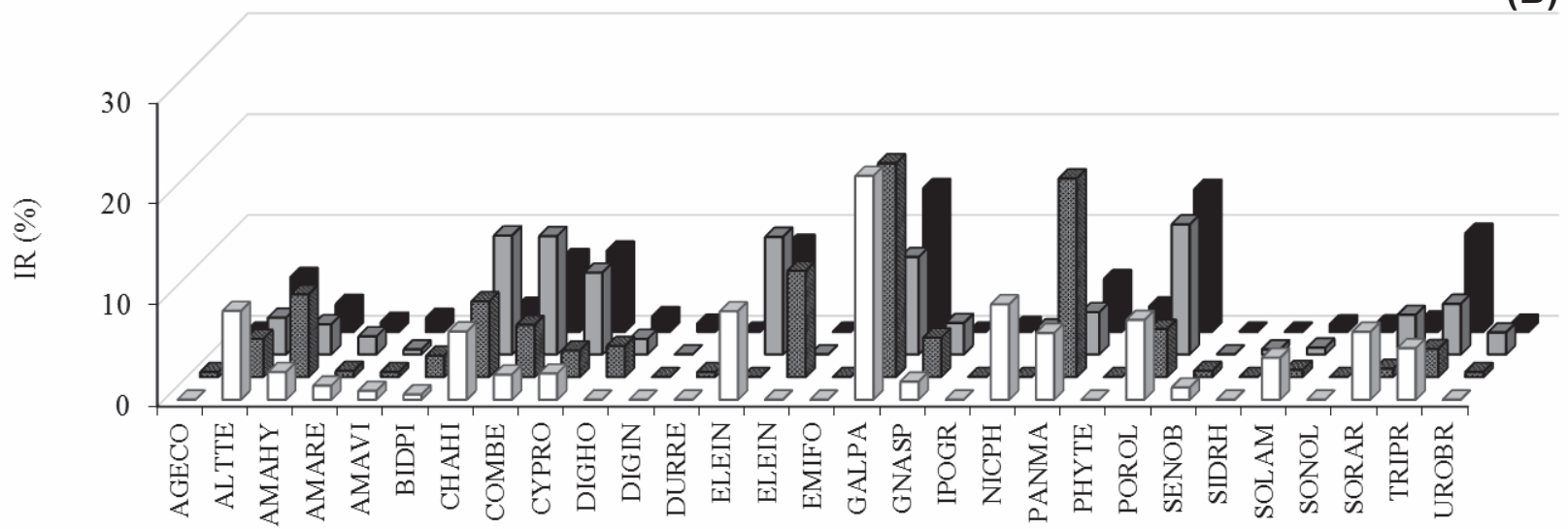

Figure 2 - Relative importance of the main weed species found on a seed bank of samples collected in different environments (I to IV), on two period of the year (rainy - A and dry season - B), knowingly I: annual culture area, II: olericulture area, III: perennial culture area and IV: grazing area. 
weed seed bank on the raw cane agroecosystem, observed the prevalence of dicotyledons.

The index of similarity of Sörensen represents the common species between two environments. In general, all environments were similar in relation to the species found (Table 3). During the rainy season, the lowest similarity was observed among the annual culture and olericulture environments; however, during the dry season, these environments were the most similar ones. The olericulture area is constantly managed, with fertility and irrigation maintenance; therefore, the dominant species are favored, and there are not many changes in relation to the weeds during the year. On the annual culture, during the dry season, with lower hydric availability, the dominant species that were more adjusted to this condition, similarly to the olericulture environment, are favored, which may have contributed for these locations to show similar results during this time. During the rainy season, high higher hydric availability on the soil, a more diversified emergence of individuals occurs, differently from the olericulture environment.

Table 3 - Sörensen similarity among the four studied environments

\begin{tabular}{|l|c|c|}
\hline \multirow{2}{*}{\multicolumn{2}{|c|}{ Types of culture }} & \multicolumn{2}{c|}{$\begin{array}{c}\text { Sörensen } \\
\text { similarity (\%) }\end{array}$} \\
\cline { 2 - 3 } & Rain & Dry \\
\hline Annual Culture x Olericulture & 76.00 & 89.47 \\
\hline Annual Culture x Perennial Culture & 84.61 & 82.05 \\
\hline Annual Culture x Grazing & 86.27 & 76.19 \\
\hline Olericulture x Perennial Culture & 90.90 & 82.92 \\
\hline Olericulture x Grazing & 83.72 & 77.27 \\
\hline Perennial Culture x Grazing & 84.44 & 88.88 \\
\hline
\end{tabular}

Considering the above-mentioned, it is concluded that the seven main species on the environments were $C$. rotundus, N. physaloides, G. parviflora, A. tenella, $P$. maximum, $P$. oleracea and E. indica. Among the studied environments, during the rainy season, the largest number of individuals was found on the annual culture, and the largest diversity, on the perennial environment. On the dry season, the number and diversity of individuals were lower and similar on all environments. The presence of weeds was similar on all environments; during the rainy season, the less similar environments were the annual culture and olericulture; however, they were the most similar ones during the dry season.

\section{REFERENCES}

Braun-Blanquet V. Fitosociología, bases para el estudio de las comunidades vegetales. Madrid: H. Blume, 1979. $820 \mathrm{p}$.

Bürger J. et al. Simulation study of the impact of changed cropping practices in conventional and GM maize on weeds and associated biodiversity. Agr Syst. 2015;137:51-63.

Caetano R.S.X. et al. "Banco" de sementes de plantas daninhas em pomar de laranjeira 'Pera'. Sci Agric. 2001;58:509-17.

Cavalcanti E.A.H., Larrazábal M.E.L. Macrozooplâncton da Zona Econômica Exclusiva do Nordeste do Brasil (segunda expedição oceanográfica - REVIZEE/NE II) com ênfase em Copepoda (Crustacea). Rev Bras Zool. 2004;21:467-475.

Concenço G. et al. Ocorrência de espécies daninhas em função de sucessões de cultivo. Planta Daninha. 2013;31:359-68.

Fernandez O. Las malezas y su evolution. Cienc Invest. 1979;35:49-59.

Ferreira E.A. et al. Levantamento fitossociológico de plantas daninhas em pastagens degradadas do Médio Vale do Rio Doce, Minas Gerais. Rev Ceres. 2014;61:502-10.

Gomes Jr F.G., Christoffoleti P.J. Biologia e manejo de plantas daninhas em áreas de plantio direto. Planta Daninha. 2008;26:789-98.

Hosseini P. et al. Weed seed bank as affected by crop rotation and disturbance. Crop Prot. 2014;64:1-6.

Ikeda S.F. et al. Banco de sementes em sistemas de cultivo lavoura-pastagem. Pesq Agropec Bras. 2007;42:1545-51.

Jakelaitis A. et al. Banco de sementes de plantas daninhas em solos cultivados com culturas e pastagens. Glob Sci Technol. 2014;7:63-73.

Kuva M.A. et al. Fitossociologia de comunidades de plantas daninhas em agroecossistema cana-crua. Planta Daninha. 2007;25:501-11.

Matloob A. et al. Weed dynamics as influenced by tillage system, sowing time and weed competition duration in dryseeded rice. Crop Prot. 2015;71:25-38. 
Mesquita M.L.R. et al. Floristic diversity of the soil weed seed bank in a rice-growing area of Brazil: in situ and ex situ evaluation. Acta Bot Bras. 2013;27:465-71.

Pelissari A. et al. Avanços no controle de plantas daninhas no sistema de integração lavoura-pecuária. Rev Syn Scy UTFPR. 2011;6.

Pitelli R.A. Plantas daninhas no sistema plantio direto de culturas anuais. Rev Plantio Direto. 1998;4:13-8.

Roberts H.A. Seed banks in the soil. Cambridge: Academic Press, 1981. 55p. Radosevich S.R., Holt J., Ghersa C.

Physiological aspects of competition. In: Radosevich S. et al. editor. Weed ecology. $2^{\text {nd }}$. ed. New York: John Wiley, 1997. p.217-301.

Santos R.C. et al. Phytosociological characterization of weed species as affected by soil management. Austr J Crop Sci. 2015;9:112-9.
Silva A.A. et al. Biologia de plantas daninhas. In: Silva A.A., Silva J.F. Tópicos em manejo de plantas daninhas. Viçosa, MG: Universidade Federal de Viçosa, 2007. p.17-61.

Silva M.R.M. et al. Banco de sementes de plantas daninhas em áreas de cultivo de arroz de sequeiro na Pré -Amazônia Maranhense. Rev Cienc Agr. 2014;57:351-7.

Singha M. et al. The critical period for weed control in dryseeded rice. Crop Prot. 2014;66:80-5.

Tursun N. et al. Nitrogen application influenced the critical period for weed control in cotton. Crop Prot. 2015;74:85-91.

Vivian R. et al. Dormência em sementes de plantas daninhas como mecanismo de sobrevivência - breve revisão. Planta Daninha. 2008;26:695-706.

Yirefu F. et al. Competitive ability of sugarcane (Saccharum officinarum L.) cultivars to weed interference in sugarcane plantations of Ethiopia. Crop Prot. 2012;32:138-43. 